\title{
PREPARASI DAN KARAKTERISASI ARANG DARI AMPAS SAGU SEBAGAI ADSORBEN DALAM MENURUNKAN KADAR COD DAN BOD LIMBAH CAIR PABRIK TAHU
}

\author{
Victor Kayadoe ${ }^{1}$, Sunarti ${ }^{1}$, Yeslia Utubira ${ }^{1}$, Nova Kayadoe ${ }^{2}$ \\ ${ }^{1}$ Departement of Chemistry-FKIP, Pattimura University Ambon \\ 2SMA Negeri 22 Maluku Tengah \\ “kayadoev27@gmail.com
}

\begin{abstract}
The preparation and characterization of charcoal from sago pulp as an adsorbent in reducing content of COD and BOD of tofu factory waste has been carried out. Sago pulp has been turned into charcoal through carbonization at $400^{\circ} \mathrm{C}$ for 2 hours. The results of charcoal characterization using XRD show that the carbon produced from sago pulp carbonization has a low crystallinity which is indicated by a wide peak at around $2 \theta$ $23^{\circ}$ which is the characteristic carbon peak. The results of characterization using Surface Area Analyzer show that the pores in the sago pulp charcoal are very few and irregular, and dominated by macropores. The results of the characterization using SEM showed that sago pulp charcoal had very few pores. The material is dominated by the residue from the results of non-porous carbonization. Performance as an adsorbent to reduce the content of $\mathrm{COD}$ and $\mathrm{BOD}$ in tofu mill wastewater by batch method shows the capacity and efficiency of adsorption on COD of $18.75 \mathrm{mg} / \mathrm{g}$ and $35.21 \%$, respectively. While capacity and efficiency of adsorption on BOD of $1.75 \mathrm{mg} / \mathrm{g}$ and $3.57 \%$, respectively.
\end{abstract}

Keyword: Charcoal, sago pulp, Adsorbant, COD, BOD

\begin{abstract}
ABSTRAK
Preparasi dan karakterisasi arang dari ampas sagu sebagai adsorben dalam menurunkan kadar COD dan BOD limbah pabrik tahu telah dilakukan. Ampas sagu dijadikan arang melalui proses karbonisasi pada suhu $400^{\circ} \mathrm{C}$ selama 2 jam. Hasil karakterisasi arang yang dihasilkan menggunakan XRD menunjukkan bahwa arang hasil karbonisasi ampas sagu memiliki kristalinitas yang rendah yang ditunjukkan dengan puncak lebar pada sekitar $2 \theta 23^{\circ}$ yang merupakan puncak karakteristik karbon. Hasil karakterisasi menggunakan Surface Area Analyzer menunjukkan pori-pori dalam arang ampas sagu sangat sedikit dan tidak teratur, serta didominasi oleh pori berukuran makro. Hasil karakterisasi menggunakan SEM menunjukkan bahwa arang ampas sagu memiliki pori yang sangat sedikit. Material didominasi oleh residu dari hasil karbonisasi yang tidak berpori. Kinerja sebagai adsorben dalam menurunkan kadar COD dan BOD limbah cair pabrik tahu secara batch menunjukkan kapasitas dan efisiensi adsorpsi terhadap kadar COD, masing-masing 18,75 mg/gdan 35,21\%, semetara BOD, masing-masing $1,75 \mathrm{mg} / \mathrm{g}$ dan $3,57 \%$.
\end{abstract}

Kata Kunci: Arang, ampas sagu, Adsorben, COD, BOD.

\section{PENDAHULUAN}

Pabrik tahu merupakan industri kecil yang umumnya menyatu dengan pemukiman penduduk. Di kota Ambon, pabrik tahu berada pada beberapa lokasi dan salah satunya di kawasan yang padat penduduknya, yakni Desa Batu Merah Kota Ambon. Pabrik tahu Desa Batu Merah berada di dekat aliran sungai yang mengalir disepanjang pemukiman penduduk. Tanpa melalui pengolahan, limbah cair dari pabrik dialirkan langsung ke badan sungai yang mengakibatkan terjadinya pencemaran air sungai. Uyara, dkk (2017) menyatakan bahwa kualitas air Sungai Batu Merah dipengaruhi oleh aktivitas masyarakat di sekitar area sumber air yang telah mempengaruhi kualitas sumber air di Desa Batu Merah terutama adalah jumlah 
penduduk yang terus meningkat dan pemanfaatan kolam penampungan air bersih sebagai kolam untuk mencuci, mandi dan berekreasi, telah mengakibatkan degradasi kualitas air tersebut yang ditunjukan oleh kandungan e. coli dan total koliform yang tinggi/melampaui standar mutu air bersih.

Pabrik tahu jarang memiliki instalasi pengolahan limbah dengan pertimbangan biaya yang sangat besar dalam pembangunan instalasi pengolahan limbah dan operasionalnya. Limbah tahu mengandung protein, bahan organik dan padatan terlarut tinggi, dengan $\mathrm{pH}$ yang rendah. Limbah tahu ini akan menimbulkan aroma yang kurang sedap sehingga mengganggu estetika dan kehidupan ekosistem sekitarnya, serta mengancam kesehatan manusia (Adack, 2013). Sementara Sepriani, dkk (2016) melaporkan pembuangan limbah cair tahu mengakibatkan penurunan kualitas sungai Paal 4, kecamatan Tikala, kota Manado.

Tingkat pencemaran air oleh limbah cair dapat ditentukan dengan mengukur kadar COD (Chemical Oxygen Demand) dan BOD (Biochemical Oxygen Demand) yang terkandung dalam limbah cair. Air dengan nilai COD dan BOD tinggi menunjukkan jumlah pencemar yang tinggi terutama pencemaran yang disebabkan oleh bahan organik (EPA, 2013).

Kadar COD dan BOD dalam limbah cair pabrik tahu Batu Merah Kota Ambon telah dilaporkan beberapa peneliti. Rasako dan Ahmad (2014) melaporkan kadar COD limbah cair pabrik tahu Batu Merah pada tahun 2013 sebesar 160 mg/L. Kadar ini dilaporkan telah melampaui batas maksimum COD limbah cair yang dapat dibuang ke lingkungan menurut Peraturan Menteri ingkungan Hidup No.03 Tahun 2010, yakni sebesar $100 \mathrm{mg} / \mathrm{L}$. Sementara Dewa dan Idrus (2017) melaporkan kadar COD dan BOD limbah cair pabrik tahu Batu Merah Kota Ambon masing-masing sebesar $1175 \mathrm{mg} / \mathrm{L}$ dan $400 \mathrm{mg} / \mathrm{L}$ pada lokasi I, dan $710 \mathrm{mg} / \mathrm{L}$ dan $385 \mathrm{mg} / \mathrm{L}$ pada lokasi II. Pada lokasi pertama, kadar $\mathrm{BOD}_{5}$ dan COD titik pertama masing-masing sebesar $400 \mathrm{mg} / \mathrm{L}$ dan $1175 \mathrm{mg} / \mathrm{L}$, sedangkan pada titik kedua $385 \mathrm{mg} / \mathrm{L}$ dan $710 \mathrm{mg} / \mathrm{L}$. Kemudian pada lokasi kedua, kadar BOD 5 dan COD titik pertama masing-masing sebesar $360 \mathrm{mg} / \mathrm{L}$ dan $768 \mathrm{mg} / \mathrm{L}$, sedangkan pada titik kedua $310 \mathrm{mg} / \mathrm{L}$ dan $384 \mathrm{mg} / \mathrm{L}$. Kondisi ini dilaporkan telah melampaui ambang batas.

Salah satu metode yang dapat digunakan untuk menurunkan kadar COD dan BOD metode adsorpsi. Keberhasilan proses adsorpsi ditentukan oleh pemilihan sifat adsorben. Adsorben harus mempunyai daya serap yang besar, zat padat yang mempunyai luas permukaan yang besar, tidak larut dalam zat cair yang akan di adsorpsi, tidak beracun dan mudah didapat, serta memiliki harga yang murah (Alzaky, 2014).

Hingga kini, karbon aktif merupakan salah satu adsorben yang masih diandalkan, karena memiliki pori dengan luas permukaan yang sangat besar sehingga mampu meningkatkan daya adsorpsinya. Untuk meningkatkan daya adsorpsinya maka bahan alam diubah menjadi karbon aktif melalui proses aktivasi (Nurhayati, dkk, 2015).

Beberapa peneliti telah melaporkan pemanfaatan karbon aktif dari bahan alam untuk menurunkan kadar COD dan BOD limbah cair. Rochma \&Titah (2017) melaporkan karbon aktif batubara dengan aktivator $\mathrm{HCl}$ mampu menurunkan kadar COD sebesar 16.444,08 mg/L dengan efisiensi penurunan $98,74 \%$ dan kadar BOD sebesar 1.640,70 mg/L dengan efisensi penurunan 92,30\%. Putri (2018) melaporkan karbon aktif kulit singkong dengan aktivator $\mathrm{NaCl}$ mampu menurunkan kadar COD sebesar 36\%. Siregar, dkk (2015) melaporkan karbon aktif dari biji kapuk dengan aktivator $\mathrm{NaHCO}_{3}$ mampu menurunkan kadar $\mathrm{COD}$ dengan efisiensi 73,28\%. Berdasarkan kajian literatur, karbon aktif memiliki kemampuan adsorpsi tinggi hingga mendekati $100 \%$, namun proses aktivasi kimia membutuhkan bahan kimia yang mahal, dan aktivasi fisika membutuhkan energi yang besar. Sementara arang eceng gondok tanpa aktivasi telah dilaporkan memiliki efisiensi penurunan kadar COD sebesar 9,302\% (Valentina, dkk, 2013). Oleh karena itu, sebelum dijadikan karbon aktif, kinerja arang tanpa aktivasi terhadap kapasitas dan efisiensi perlu diuji untuk mengetahui kemampuannya dalam menurunkan kadar COD dan BOD dalam limbah cair.

Ampas sagu sampai saat ini belum dimanfaatkan secara optimal dan hanya digunakan sebagai pakan ternak. Sementara berdasarkan komposisi kimianya, ampas sagu merupakan salah satu limbah pertanian yang berpotensi sebagai prekursor dalam pembuatan arang atau karbon. Simanihuruk, dkk (2013) melaporkan bahwa ampas sagu mengandung 42,5\% NDF dan 27,78\% ADF. NDF (Neutral Detergent Fiber), terdiri dari hemiselulosa, protein, selulosa, lignin, dan lignoselulosa. Sementara ADF (Acid Detergent Fiber), terdiri dari selulosa dan Ignin. Komponen- 
kompen ini jika dipirolisis dapat menghasilkan material karbon dengan karakteristik tertentu yang sangat efektif dalam pengolahan limbah cair. Untuk mengetahui karakteristik arang atau karbon yang dihasilkan, telah dilakukan karakterisasi menggunakan XRD, dan SEM. Arang hasil karbonisasi ampas sagu digunakan untuk menurunkan kadar COD dan BOD limbah cair pabrik tahu melalui adsorpsi secara batch.

\section{METODE PENELITIAN}

\section{A. Preparasi Arang Ampas Sagu}

Ampas sagu di ambil dari Desa Waai Kecamatan Salahutu, Kabupaten Maluku Tengah. Ampas sagu dicuci bersih, dijemur hingga kering, dipotong kecil-kecil dan dilakukan proses karbonisasi pada suhu $400^{\circ} \mathrm{C}$ selama 2 jam menggunakan tanur. Setelah karbonisasi, karbon yang dihasilkan didinginkan. Untuk keseragaman semua sampel ini diaduk merata secara homogen dengan menggunakan batang pengaduk, kemudian dihaluskan menggunakan lumpang dan alu. Serbuk karbon yang sudah halus, kemudian diayak dengan menggunakan ayakan berukuran 100 mesh untuk mendapatkan ukuran partikel yang homogen. Arang yang telah diperoleh selanjutnya dikarakterisasi menggunakan instrument XRD (Philips Analytical) dan SEM (EVO® MA 10).

\section{B. Penurunan kadar COD dan BOD dengan Metode Adsorpsi}

Proses adsorpsi terhadap limbah cair pabrik tahu dilakukan secara batch dengan mengambil sebanyak $250 \mathrm{~mL}$ limbah cair tahu dimasukkan ke dalam erlenmeyer, setelah itu ditambahkan 1 gram arang ampas sagu. Campuran tersebut diaduk menggunakan pengaduk magnet selama 60 menit. Setelah itu disaring menggunakan kertas saring, filtratnya ditampung untuk diuji kadar COD \& BOD. Kadar COD dianalisis menggunakan metode refluks, sedangkan analisis BOD menggunakan metode titrimetri.

C. Penentuan Kapasitas dan Efisiensi Penurunan Kadar COD dan BOD

Berdasarkan kadar COD dan BOD sebelum dan sesudah adsorpsi, dihitung kapasitas dan efisiensi penurunan kadar COD dan BOD oleh arang ampas sagu, menggunakan persamaan 1 dan 2.

$$
q_{\mathrm{t}}=\frac{c_{\mathrm{p}}-C_{\mathrm{m}}}{\mathrm{m}} \times V
$$

Keterangan:

$q_{t}=$ kapasitas adsorpsi per massa adsorben $(\mathrm{mg} / \mathrm{g})$

$C_{0}=$ kadar COD/BOD awal dalam limbah tahu $(\mathrm{mg} / \mathrm{L})$

$C_{e}=$ kadar COD/BOD dalam limbah tahu setelah teradsorpsi $(\mathrm{mg} / \mathrm{L})$

$m=$ massa karbon aktif $(\mathrm{g})$

$V=$ volume sampel limbah tahu $(\mathrm{L})$

$$
\text { Efisiensi Adsorpsi }(\%)=\frac{c_{p}-C_{m}}{c_{w}} \times 100 \%
$$

Keterangan:

$C_{0}=$ kadar COD/BOD sampel limbah tahu awal $(\mathrm{mg} / \mathrm{L})$

$C_{e}=$ kadar COD/BOD sampel limbah tahu setelah adsorpsi $(\mathrm{mg} / \mathrm{L})$ 


\section{HASIL PENELITIAN}

\section{A. Preparasi Arang dari Ampas Sagu}

Arang sebagai adsorben dalam penelitian ini disiapkan dengan cara karbonisasi ampas sagu dalam reaktor tertutup untuk menghindari kontak langsung dengan $\mathrm{O}_{2}$ di atmosfer agar tidak terjadi oksidasi berlanjut yang dapat menyebabkan karbon menjadi abu (Labanni, dkk. 2015). Proses karbonisasi ampas sagu secara pirolisis lambat menggunakan tanur secara bertahap sampai tercapai suhu $400{ }^{\circ} \mathrm{C}$ dengan waktu tinggal 2 jam hingga menyisahkan bahan yang mengandung banyak karbon (Ramadhani, dkk, 2020). Pada kondisi ini, Siregar dkk (2015) melaporkan telah diperoleh luas permukaan arang aktif yang lebih besar dibandingkan perlakuan suhu dan waktu lainnya, yakni $27,54 \mathrm{~m}^{2} / \mathrm{g}$.

Selama proses karbonisasi senyawa-senyawa volatile akan menguap dan terjadi dekomposisi senyawa-senyawa yang mengandung karbon sehingga menyisakan material karbon berpori. Pada suhu $100^{\circ} \mathrm{C}-150^{\circ} \mathrm{C}$ terjadi penguapan air, $200^{\circ} \mathrm{C}-250^{\circ} \mathrm{C}$ terjadi dekomposisi hemiselulosa, dan pada suhu $280^{\circ} \mathrm{C}-370^{\circ} \mathrm{C}$ terjadi dekomposisi selulosa dan lignin (Yuliusman, 2016). Sementara Arsad dan Hamdi (2010) menyatakan bahwa proses pembentukan karbon terjadi pada suhu $400^{\circ} \mathrm{C}$. Karbon hasil karbonisasi berwarna hitam sebagaimana yang ditunjukkan pada Gambar 1.
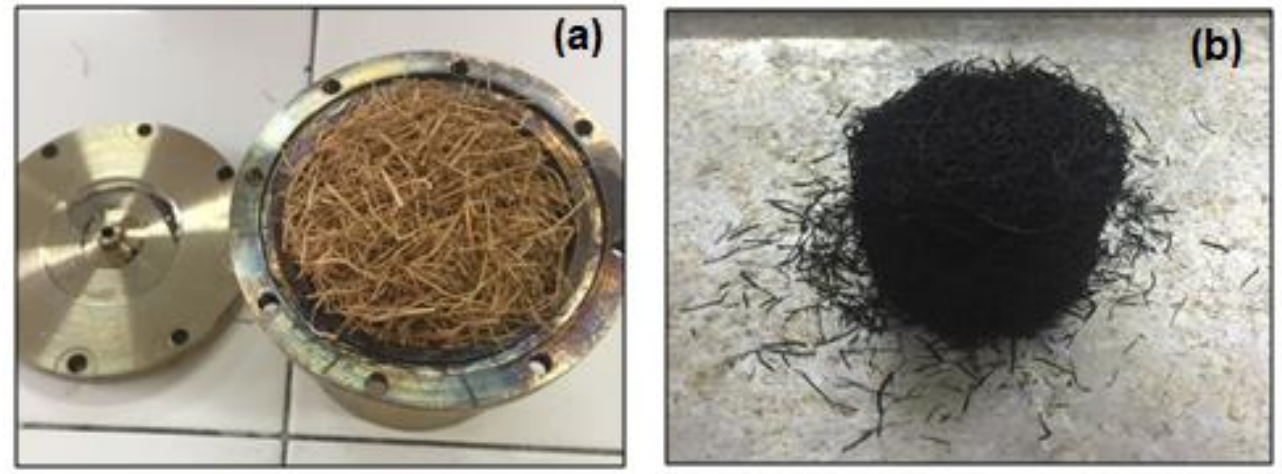

Gambar 1. Ampas sagu (a) dan arang ampas sagu setelah karbonisasi (b)

\section{B. Hasil Karakterisasi Arang Ampas Sagu Menggunakan XRD (X-Ray Diffraction)}

Serbuk Arang hasil karbonisasi dikarakterisasi menggunakan XRD bertujuan untuk mengetahui kristalinitas dan struktur arang yang dihasilkan. Difraktogram arang ampas sagu pada rentang sudut difraksi $5^{\circ}-80^{\circ}$ ditunjukkan pada Gambar 2 .

Berdasarkan Difraktogram pada Gambar 2, terlihat bahwa arang hasil karbonisasi ampas sagu memiliki kristalinitas yang rendah, ditunjukkan dengan puncak lebar pada sudut $(2 \theta)$ sekitar 23․ yang merupakan puncak karakteristik karbon (Marsh dan Rodriguez-Reinoso, 2006; Mulyati dan Pujiono, 2017). Hal ini menunjukkan bahwa arang ampas sagu memiliki struktur amorf dengan permukaan yang tidak teratur. Difraksi pada sudut sekitar $20^{\circ}$ dihasilkan dari ketidakteraturan karbon yang terhibridisasi $\mathrm{sp}^{2}$ dan menunjukkan ketidakteraturan kisi dalam bentuk morfologi lembaran graphene melengkung, bola, ujung tabung dan lain-lain (Manoj, 2016). 


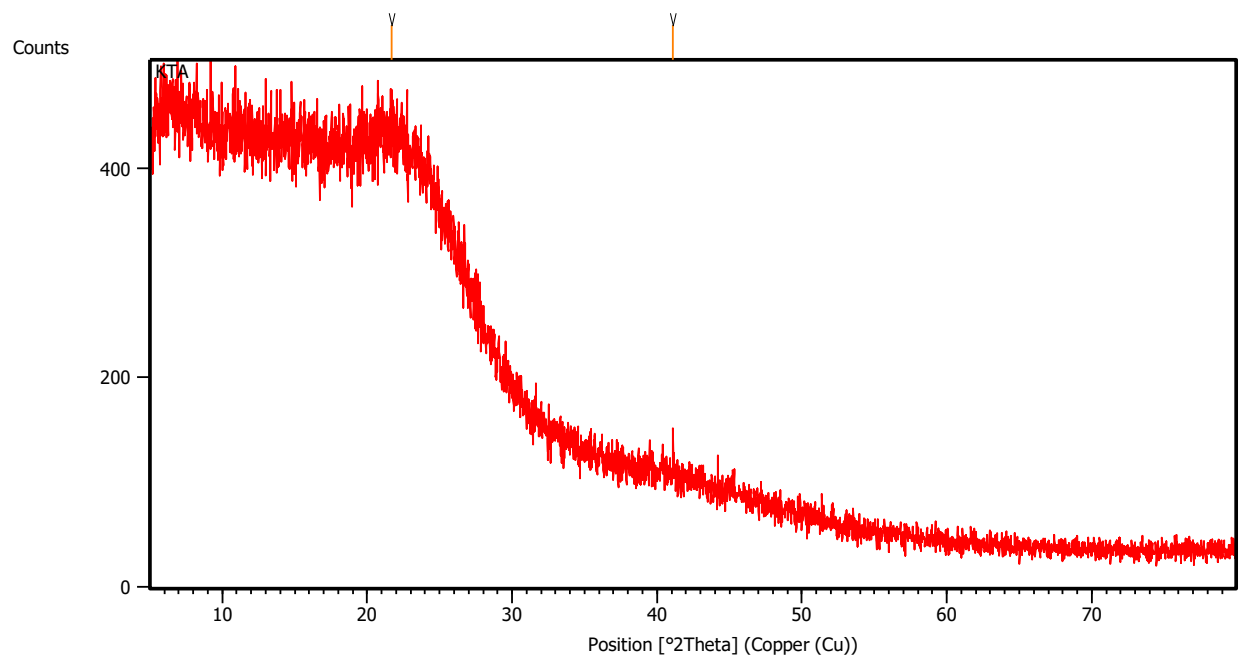

Gambar 2. Difraktogram Arang Ampas Sagu

Beberapa peneliti telah melaporkan adanya puncak lebar pada sudut sekitar $23^{\circ}$ dari arang atau karbon hasil karbonisasi biomassa, diantaranya ampas tebu (Mulyati dan Pujiono, 2017) dan tempurung kelapa sawit (Gustama, 2012). Selain itu, difraktogram menunjukkan adanya puncak lebar pada sekitar $2 \theta 42^{\circ}$. Manoj (2016) menyatakan bahwa kedua puncak lebar ini menunjukkan bahwa struktur kisi lapisan karbonnya tidak teratur. Sementara Mohan, et al (2012) menyatakan adanya puncak lebar pada $2 \theta$ sekitar $25^{\circ}$ menunjukkan difraksi bidang 002 dari karbon dengan morfologi grafit dan puncak pada $2 \theta$ sekitar $42^{\circ}$ menunjukkan difraksi bidang (100) dari karbon dengan morfologi graphene. Hal ini menunjukkan adanya kisi grafit heksagonal yang tidak teratur dari material arang yang dihasilkan.

\section{Hasil Karakterisasi Menggunakan Scanning Electron Microscope}

Karakterisasi terhadap arang ampas sagu menggunakan Scanning Electron Microscope (SEM) bertujuan untuk mengetahui morfologi dan sebaran pori pada permukaan material tersebut. Morfologi arang ampas sagu ditunjukkan pada Gambar 3.

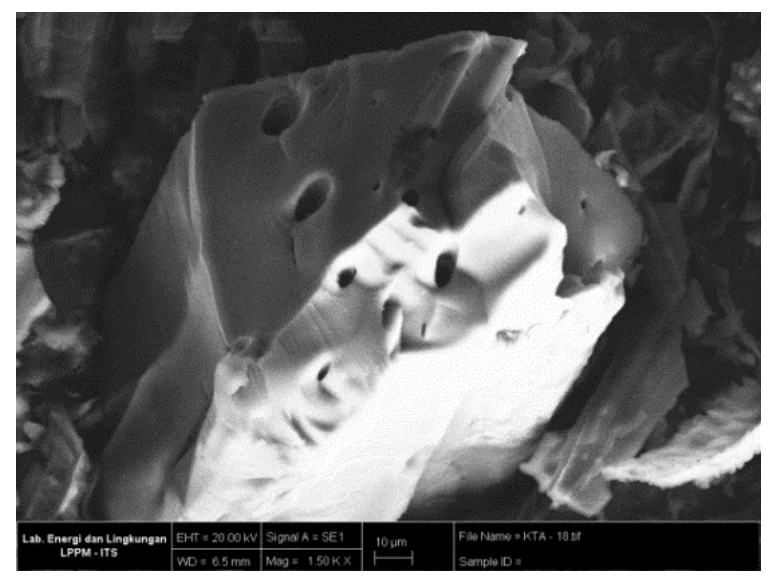

Gambar 3. Morfologi Arang Ampas Sagu menggunakan SEM (Perbesaran 1500 kali) 
Berdasarkan Gambar 3, terlihat bahwa arang ampas sagu memiliki morfologi yang tidak beraturan dengan jumlah pori yang sangat sedikit. Material didominasi oleh residu dari hasil karbonisasi yang tidak berpori. Pori-pori yang dihasilkan diakibatkan adanya penguapan zat volatile dan dekomposisi senyawa-senyawa yang mengandung karbon saat proses karbonisasi (Marsh dan Rodriguez-Reinoso, 2006., Yuliusman, 2016). Verayana, dkk (2018) menyatakan bahwa pori arang tanpa aktivasi sebagian besar masih tertutup oleh hidrogen, ter, dan senyawa organik lain yang komponennya terdiri dari abu, air, nitrogen, dan sulfur. Hasil ini mengkonfirmasi hasil karakterisasi menggunakan XRD yang menunjukkan bahwa karbon aktif yang dihasilkan bersifat amorf.

\section{Hasil Penurunan Kadar COD dan BOD Limbah Cair Pabrik Tahu}

Sebelum proses adsorpsi, kadar COD dan BOD dianalisis untuk mengetahui kandungan awal dalam limbah tahu, serta dapat diketahui gambaran kontribusi kandungan COD dan BOD oleh limbah tersebut yang masuk ke dalam perairan. Setelah itu proses adsorpsi dilakukan dan dihitung kapasitas dan efsiensi adsorpsi karbon aktif dalam menurunkan kandungan COD dan BOD. Hasilnya ditunjukkan pada Tabel 1.

Tabel 1. Kapasitas dan Efisiensi Adsorpsi COD dan BOD menggunakan Karbon Aktif Ampas Sagu

\begin{tabular}{|c|c|c|c|c|}
\hline \multirow[b]{2}{*}{ Parameter } & \multicolumn{2}{|c|}{ Kadar (mg/L) } & \multirow{2}{*}{$\begin{array}{c}\text { Kapasitas } \\
\text { Adsorpsi } \\
\text { (mg/g) }\end{array}$} & \multirow{2}{*}{$\begin{array}{c}\text { Efisiensi } \\
\text { Adsorpsi } \\
\text { (\%) }\end{array}$} \\
\hline & $\begin{array}{l}\text { Sebelum } \\
\text { Adsorpsi }\end{array}$ & $\begin{array}{l}\text { Setelah } \\
\text { Adsorpsi }\end{array}$ & & \\
\hline COD & 213 & 138 & 18,75 & 35,21 \\
\hline BOD & 196 & 189 & 1,75 & 3,57 \\
\hline
\end{tabular}

Berdasarkan data pada Tabel 1, terlihat bahwa kadar COD dan BOD awal dalam limbah cair pabrik tahu melampaui ambang batas sesuai Peraturan Menteri ingkungan Hidup No.03 Tahun 2010, sehingga sangat tidak layak di buang ke perairan. Kandungan COD lebih tinggi dibandingkan BOD menunjukkan bahwa, senyawa yang terkandung dalam limbah cair pabrik tahu didominasi oleh senyawa organik yang dapat terurai secara kimia.

Hasil adsorpsi menunjukkan bahwa arang aktif mampu menurunkan kandungan COD dan BOD dalam limbah cair pabrik tahu. Kapasitas dan Efisensi adsorpsi arang ampas sagu terhadap penurunan kadar COD, masing-masing $18,75 \mathrm{mg} / \mathrm{g}$ dan $35,21 \%$ dan terhadap penurunan BOD, masing-masing $1,75 \mathrm{mg} / \mathrm{g}$ dan 3,57\%. Efisiensi adsorpsi arang ampas sagu terhadap COD lebih besar dibandingkan dengan arang eceng gondong tanpa aktivasi seperti yang telah dilaporkan Valentina, dkk (2013) dengan waktu kontak yang sama (60 menit), yakni 9,302\%. Namun efisiensi adsorpsi terhadap BOD masih lebih rendah. Hal ini dapat disebabkan kandungan awal COD dan BOD yang berbeda, karakteristik arang yang dihasilkan, serta perbedaan variabel lainnya yang mempengaruhi proses adsorpsi. Rendahnya efisiensi adsorpsi yang diperoleh dikaitkan banyaknya residu hasi karbonisasi yang tidak berpori.

\section{KESIMPULAN}

Berdasarkan hasil penelitian, disimpulkan bahwa:

1. Hasil karakterisasi menggunakan XRD, Surface Area Analyzer dan SEM menunjukkan bahwa arang hasil karbonisasi ampas sagu memiliki kristalinitas yang rendah dan didominasi oleh residu dari hasil karbonisasi yang tidak berpori.

2. Kinerja sebagai adsorben dalam menurunkan kadar COD dan BOD limbah cair pabrik tahu secara batch menunjukkan kapasitas dan efisiensi adsorpsi terhadap kadar COD, masingmasing 18,75 mg/gdan 35,21\%, semetara BOD, masing-masing $1,75 \mathrm{mg} / \mathrm{g}$ dan 3,57\%. 


\section{UCAPAN TERIMA KASIH}

Ucapan terima kasih disampaikan kepada Rektor Universitas Pattimura dan Dekan FKIP Universitas Pattimura yang telah memberikan Dana Hibah Unggulan Universitas Tahun 2019, serta semua pihak yang turut mendukung proses penelitian hingga penulisan jurnal ini.

\section{DAFTAR PUSTAKA}

Arsad, E., Hamdi, S. 2010. Review: Teknologi Pengolahan dan Pemanfaatan Karbon Aktif untuk Industri. Jurnal Riset Industri Hasil Hutan. Vol. 2, No.2, hal. 43-51.

Adack, J. 2013. Dampak Pencemaran Limbah Pabrik Tahu Terhadap Lingkungan Hdup. Lex Administratum, Vol.I, No.3, hal.78-87.

Alzaky, Z. 2014. Pengaruh Penambahan Lempung dengan Jenis Berbeda pada Sintesis Komposit Fe3O4-Lempung. Skripsi. Program Studi Kimia, Fakultas Sains dan Teknologi, UIN Sunan Kaljaga, Yogyakarta.

Dewa, R. P., Idrus, S. 2017, Identifikasi Cemaran Air Limbah Industri Tahu di Kota Ambon, Majalah BIAM 13 (02), hal.11-15. Kementerian Perindustrian Republik Indonesia. e-ISSN. 25484842, p-ISSN. 0215-1464.

Environmental Protection Agency. 2013. Domestic Waste Water Treatment Systems. Ireland: wexford.

Gustama, A. 2012. Pembuatan Arang Aktif Tempurung Kelapa Sawit sebagai Adsorben dalam Pemurnian Biodiesel. Skripsi, Fakultas Teknologi Pertanian, Institut Pertanian Bogor, Bogor.

Labanni, A., Zakir, M., Maming. 2015. Sintesis dan Karakterisasi Karbon Nanopori Ampas Tebu (Saccharum officianarum) dengan Aktivator $\mathrm{ZnCl}$ melalui Iradiasi Ultrasonik sebagai Bahan Penyimpan Energi Elektrokimia. Hasanuddin University Repository.

Manoj, B. A 2016. Comprehensive Analysis of Various Structural Parameters of Indian Coals with the Aid of Advanced Analytical Tools. Int J Coal Sci Technol, DOI 10.1007/s40789-0160134-1.

Marsh, H., Rodriguez-Reinoso, F. 2006. Activated Carbon. Elsevie Science \& Technology Books, ISBN. 0080444636.

Mohan, A. N., Manoj, B. 2012. Synthesis and Characterization of Carbon Nanospheres from Hydrocarbon Soot. International Journal of Electrochemical Science, Vol.7, 9537-9549.

Mulyati, T. A., Pujiono, F. E. 2017. Preparasi dan Karakterisasi Karbon Aktif dari Limbah Ampas Tebu Menggunakan Aktivator $\mathrm{KOH}$. Indonesian Chemistry and Application Journal (ICAJ), Vol. 1, No.2, hal. 1-7. ISSN. 2549-2314.

Nurhayati, I., Sutrisno, J., Pungut, Sembodo, B. P. 2015. Arang Aktif Ampas Tebu Sebagai Media Adsorpsi Untuk Meningkatkan Kualitas Air Sumur Gali. WAKTU, Jurnal Teknik UNIPA, Universitas PGRI Adi Buana (UNIPA), Surabaya, Vol. 13, No.02, hal. 9-18, ISSN. 14121867.

Putri, L. I. 2018, Uji Potensi Penggunaan Karbon Aktif dalam Penurunan Bahan Organik Limbah Cair Industri Tahu di KelurahanPakunden Kota Blitar, Skirpsi, Program Studi Manajemen Sumberdaya Perairan, Universitas Brawijaya, Malang.

Ramadhani, L. F., Nurjannah, I. M., Yulistiana, R., Saputro, E. A. 2020. Review: Teknologi Aktivasi Fisika pada Pembuatan Karbon Aktif dari Tempurung Kelapa. Jurnal Teknik Kimia, No.2, Vol. 26, hal. 42-53.

Rasako, H., Ahmad, R. 2014. Pemanfaatan Biji Kelor (Moringa Oleifera) sebagai Koagulan Alternatif dalam Proses Penjernihan Limbah Cair Industri Tahu Negeri Batu Merah Kota Ambon Tahun 2013, Jurnal Kesehatan Terpadu, Jilid 5, Nomor 1, hal. 45-52. ISSN. 1978-7766.

Rochma, N., Titah, H. S., 2017, Penurunan BOD dan COD Limbah Cair Industri Batik Menggunakan Karbon Aktif Melalui Proses Adsorpsi Secara Batch, JURNAL TEKNIK 
ITS Vol. 6, No. 2, ISSN: 2337-3539 (2301-9271 Print).

Sepriani, Abidjulu, J., Kolengan, H. S. J., 2016. Pengaruh Limbah Cair Industri Tahu terhadap Kualitas Air Sungai Paal 4 Kecamatan Tikala kota Manado, Chem. Prog. Vol. 9. No. 1, hal. 35-40.

Simanihuruk, K., Antonius, Sirait, J. 2013. Penggunaan Ampas Sagu sebagai Campuran Pakan Komplit Kambing Boerka Fase Pertumbuhan, Conference Paper: Seminar Nasional Teknologi Peternakan dan Veteriner. Indonesia. hal. 373-381.

Siregar, R. D., Zaharah, T. A., Wahyuni, N., 2015, Penurunan Kadar COD (Chemical Oxygen Demand) Limbah Cair Industri Kelapa Sawit Menggunakan Arang Aktif Biji Kapuk (Ceiba Petandra), JKK, Vol. 4, No. 2, halaman 62-66, ISSN 2303-1077.

Valentina, A. E., Miswadi, S. S., Latifah. 2013. Pemanfaatan Arang Eceng Gondok dalam Menurunkan Kekeruhan, COD, BOD, pada Air Sumur. Indonesian Journal of Chemical Science, Vol. 2, No. 2, hal. 84-89, ISSN NO 2252-6951.

Verayana, Paputungan, M., lyabu, H. 2018. Pengaruh Aktivator $\mathrm{HCl}$ dan $\mathrm{H}_{3} \mathrm{PO}_{4}$ terhadap Karakteristik (Morfologi Pori) Arang Aktif Tempurung Kelapa serta Uji Adsorpsi pada Logam Timbal (Pb). Jurnal Entropi, Vol.13, No.1, hal. 67-75.

Yuliusman, 2016. Pembuatan Karbon Aktif dari Tempurung Kelapa Melalui Aktifasi Kimia dengan $\mathrm{KOH}$ dan Fisika dengan $\mathrm{CO}_{2}$. Seminar Nasional Teknik Kimia Soebardjo Brotohardjono XII, Surabaya. ISSN. 1978-0427. 